\title{
Influence of raw milk microflora on the characteristics of Swiss-type cheeses: II. Biochemical and sensory characteristics
}

\author{
Y Demarigny, E Beuvier, S Buchin, S Pochet, R Grappin
}

Station de Recherches en Technologie et Analyses Laitières, Inra, BP 89, 39801 Poligny Cedex, France

\begin{abstract}
Summary - Using the same microfiltered milk, three 'raw milk' Swiss-type minicheeses were made after addition of three different retentates; one, remaining bacteria-free, was used as reference. The experiment was repeated three times at two different seasons. Factorial discriminant analyses were made on biochemical, physico-chemical and microbiological data at 12 weeks (end of warm storage, $18^{\circ} \mathrm{C}$ ) and 24 weeks (end of cold storage, $7^{\circ} \mathrm{C}$ ). At each ripening period, 'raw milk' cheeses were easily and significantly separated from the reference cheese. At 12 weeks, the three 'raw milk' cheeses were separated on the basis of propionic fermentation products, and to a lesser extent on proteolysis and levels of facultatively heterofermentative lactobacilli and starter lactic acid bacteria. At 24 weeks, differentiation was mainly based on proteolysis, since volatile fatty acids and lactate concentrations were nearly the same, irrespective of the cheeses. The same conclusions were drawn for winter and autumn cheeses. Based on sensory evaluations made at the end of ripening, it was also possible to differentiate between the different 'raw milk' cheeses in winter and in autumn. Reference cheeses were always clearly separated from the other cheeses. The qualitative and quantitative importance of the indigenous microflora of milk on the biochemical and sensory characteristics of Swiss-type cheeses has been discussed.
\end{abstract}

Swiss-type minicheese / microflora / proteolysis / volatile fatty acid / sensory analysis

Résumé — Influence de la microflore du lait cru sur les caractéristiques des fromages à pâte pressée cuite : II. Caractéristiques biochimiques et sensorielles. Des minifromages à pâte pressée cuite ont été fabriqués à partir de lait cru microfiltré, auquel étaient ajoutés des rétentats provenant de trois origines différentes. Chacun des trois rétentats issus de la microfiltration était réincorporé dans le lait microfiltré de mélange, pour obtenir trois fromages dits au «lait cru». Le lait microfiltré ser-

Oral communication at the IDF Symposium 'Ripening and Quality of Cheeses', Besançon, France, February 26-28, 1996. 
vait de témoin. L'expérimentation a été répétée trois fois, en automne et en hiver. Une analyse factorielle discriminante a été effectuée, pour chaque saison, sur les données biochimiques, physico-chimiques et microbiologiques collectées à 12 semaines (sortie cave chaude, $18^{\circ} \mathrm{C}$ ) et à 24 semaines (sortie cave froide, $7^{\circ} \mathrm{C}$ ). À chaque stade, les fromages au «lait cru» se différenciaient significativement du témoin. De plus, à 12 semaines, il était déjà possible de caractériser les trois fromages au «lait cru», principalement à partir de leur profil fermentaire, et dans une moindre mesure sur les niveaux de protéolyse et de certaines populations microbiennes (lactobacilles hétérofermentaires facultatifs, bactéries lactiques du levain). À 24 semaines, la différenciation portait essentiellement sur les niveaux de certains paramètres de protéolyse, les concentrations en lactate, acétate et propionate étant identiques quels que soient les fromages. Des analyses sensorielles, réalisées sur les minifromages en fin d'affinage, ont permis de discriminer les trois origines des fromages au lait cru en hiver et en automne. Les fromages témoins étaient aussi clairement séparés des autres fromages. L'importance qualitative et quantitative de la microflore originelle du lait sur les caractéristiques biochimiques et sensorielles des fromages à pâte pressée cuite, est discutée.

fromage à pâte pressée cuite / microflore / protéolyse / acide gras volatil / analyse sensorielle

\section{INTRODUCTION}

During ripening, biochemical characteristics of Swiss-type cheeses change as a consequence of bacterial development and enzymatic activities (Mocquot, 1979). These modifications allow cheeses to acquire typical texture and flavour. The activity of microorganisms includes two major transformation groups: catabolism of lactate with production of acetate $\left(\mathrm{C}_{2}\right)$, propionate $\left(\mathrm{C}_{3}\right)$ and $\mathrm{CO}_{2}$, and hydrolysis of proteins and peptides in smaller compounds. However, many other changes can occur, which are either essential (eg, production of volatile products responsible for aroma development), or undesirable (eg, release of rancid fatty acids, textural defects linked to secondary fermentation).

$\mathrm{C}_{2}$ and $\mathrm{C}_{3}$ are essentially produced by propionibacteria (Langsrud and Reinbold, 1973), although $\mathrm{C}_{2}$ can also come from facultatively heterofermentative lactobacilli metabolism (Thomas, 1987). These two compounds play a significant role in the definition of the typical flavour of Swiss-type cheeses (Bosset et al, 1993), whereas $\mathrm{CO}_{2}$ is responsible for 'opening'. Moreover, the conversion of lactate into volatile fatty acids allows $\mathrm{pH}$ to increase dur- ing ripening, which further favours bacterial growth.

Proteolysis participates in flavour development, either by producing aroma precursors and compounds, or by releasing flavour molecules fixed on proteins (Adda et al, 1982). However, Adda (1987) also noticed that small peptides can interfere with calcium and magnesium ions to produce a broth-like aroma. Finally, it is known that bitterness is due to the appearance in the cheese of small hydrophobic peptides (Lemieux and Simard, 1991). According to Grappin et al (1985) and Rank et al (1985), proteolysis can be separated into two distinct parts:

- The extent of casein breakdown measured by electrophoresis is described as primary proteolysis. During ripening, this catabolism involves enzymes from the milk - plasmin, cathepsin D - and from rennet. However, bacterial enzymes also participate in the hydrolysis of caseins. Hence, lactic acid bacteria possess a wide proteolytic system which is more efficient for thermophilic lactobacilli than for mesophilic lactobacilli, thermophilic streptococci being the least active (Steffen et al, 1987). Concerning propionibacteria, these are gener- 
ally weakly proteolytic (Gautier et al, 1993), although Dupuis et al (1995) identified two enzymatic activities acting on $\beta$ - and $\alpha_{\mathrm{S} 1}$-casein. Micrococci preferentially transform $\beta$-casein, but may hydrolyse other caseins as well (Bhowmik and Marth, 1990).

- Peptides of high molecular weight resulting from casein breakdown are further degraded into small peptides, amino acids and other nitrogen compounds such as $\mathrm{NH}_{3}$. This catabolism is described as secondary proteolysis and is essentially due to the action of enzymes from bacteria, either during their growth or after lysis. Particularly, Lactobacillus species possess many peptidases, most of them being intracellular, although some membrane-associated peptidases have been identified (Khalid and Marth, 1990). Many peptidases from thermophilic streptococci have been described, mainly from intracellular extracts (Monnet et al, 1995). Other microorganisms present in ripened cheeses may also participate in secondary proteolysis such as propionibacteria, which are particularly important in Swiss-type cheeses. These microorganisms exhibit an intracellular aminopeptidase activity, which is, eg, responsible for the release of proline in the medium (Dupuis, 1994).

In the previous article, we showed the evolution curves of the different microbial populations of Swiss-type minicheeses made from 'raw milk', with a special emphasis on facultatively heterofermentative lactobacilli (Demarigny et al, 1996). This second paper deals with the biochemical aspects, ie, volatile fatty acids and proteolysis and with the sensory quality in order to assess the role of indigenous milk microflora on the characteristics of 'raw milk' cheeses.

\section{MATERIALS AND METHODS}

\section{Cheese-making}

Three bulk milks were collected from three Comté cheese plants (A, B and C), located at different altitudes in the Jura mountains, and known to produce cheeses of different flavours.
After skimming and microfiltration of each milk, $\mathrm{A}, \mathrm{B}$ and $\mathrm{C}$ creams were mixed, pasteurised and added to the $\mathrm{A}, \mathrm{B}$ and $\mathrm{C}$ commingled microfiltered milk to obtain a microfiltered milk of the same physico-chemical composition. Retentates $\mathrm{A}, \mathrm{B}$ and $\mathrm{C}$ were then reincorporated according to the protocol described in figure 1 . The experiment was repeated three times within two weeks, in winter and in autumn. Each time four minicheeses were made, three with different retentates (A, B and C) and one reference ( $\mathrm{T}$ ) with no further retentate added. The 24 cheeses were ripened for three weeks at $14{ }^{\circ} \mathrm{C}$, then nine weeks at $18{ }^{\circ} \mathrm{C}$ (warm room) and finally 12 weeks at $7{ }^{\circ} \mathrm{C}$ (cold room). More technological details are given in our previous paper (Demarigny et al, 1996).

\section{Physico-chemical and biochemical analyses of cheeses}

Several parameters were followed, ie: $\mathrm{pH}$ : an electrode was put in close contact with grated cheese packed in a cylinder tube; dry matter (DM) expressed in $\mathrm{g} / 100 \mathrm{~g}$ of cheese; around $1.5 \mathrm{~g}$ of grated cheese was dried for $24 \mathrm{~h}$ in an oven at $103^{\circ} \mathrm{C}$ (FIL-IDF, 1982); fat content was assessed by the butyrometric method of Heiss (1961); moisture in non-fat cheese (MNFC) was then calculated; calcium ( $\mathrm{Ca}$, expressed in $\mathrm{mg} / 100 \mathrm{~g}$ non-fat dry matter) was estimated by the method of Pearce (1977) adapted to cheese by Jeunet (unpubl results); $\mathrm{NaCl}$ (S/M\%, expressed in salt in moisture) was determined with a Corning 926 chlorometer, as described by Bouton et al (1994); total nitrogen (TN), water-soluble nitrogen (WSN) and phosphotungstic acid-soluble nitrogen (PTASN) were estimated according to the method described by Bouton et al (1994) and expressed in two ratios: WSN/TN (\%) and PTASN/TN (\%); D- and L-lactate (expressed in $\mathrm{mg} / 100 \mathrm{~g}$ of cheese) were determined according to the enzymatic method of Boehringer Mannheim (ref 1112821, Meylan, France); volatile fatty acids (VFA, expressed in $\mathrm{mg} / 100 \mathrm{~g}$ or $\mu \mathrm{mol} / 100 \mathrm{~g}$ of cheese) were determined according to the method described by 


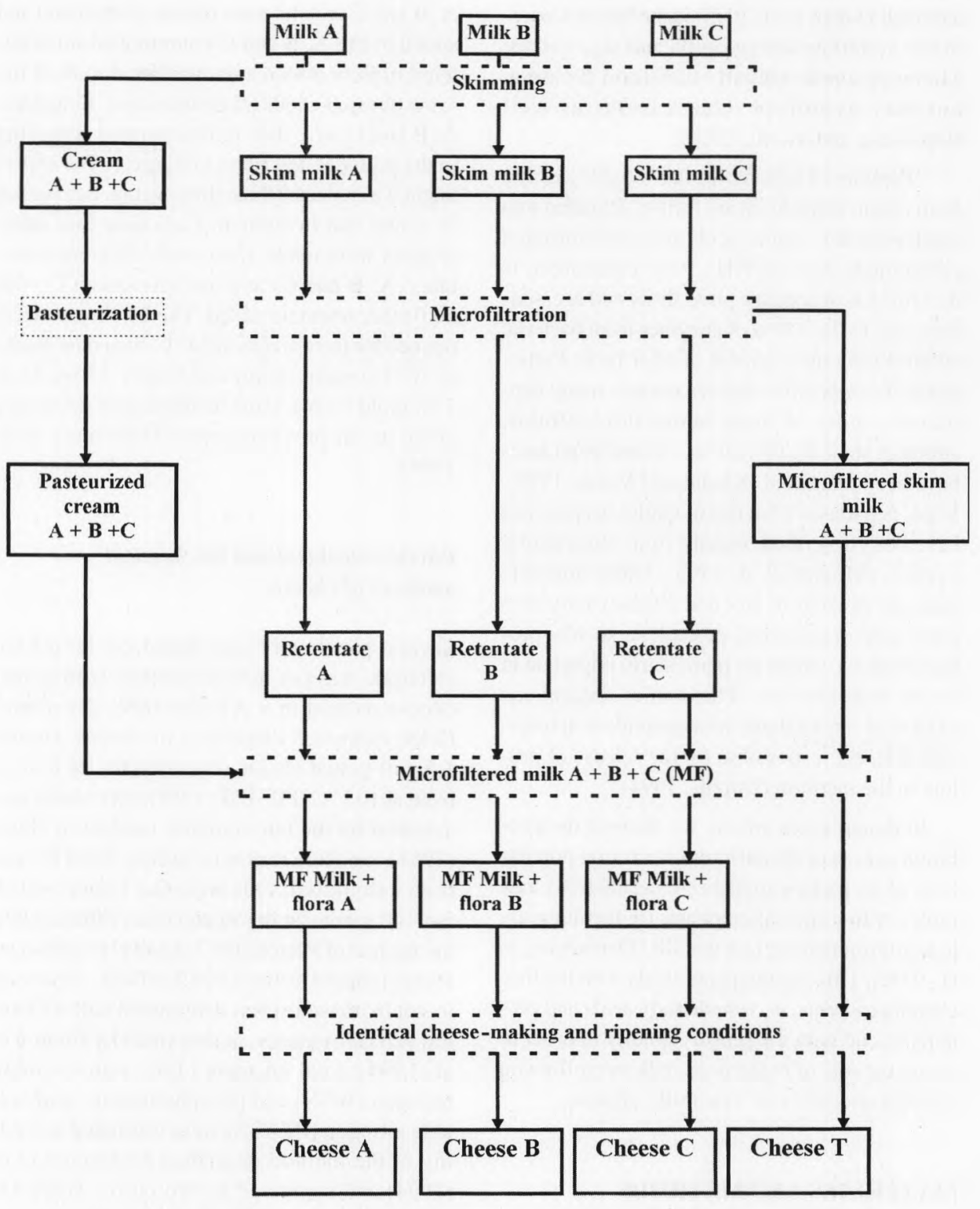

4 cheeses $\times 3$ repetitions $\times 2$ seasons $=24$ cheeses

Fig 1. Principle of cheese-making.

Schéma de fabrication des fromages. 
Berdagué et al (1987), with technical parameters identical to those reported by Bouton et al (1994); main caseins ( $\alpha_{S 1}$ and $\beta$ ) and their degradation products $\left(\alpha_{S_{1}}-1, \gamma_{1}, \gamma_{2}\right.$ and $\left.\gamma_{3}\right)$ were assessed by urea-polyacrylamide gel electrophoresis (urea-PAGE), according to the method described by McSweeney et al (1993b); peptides in cheese were determined according to reverse-phase high-pressure liquid chromatography (RP-HPLC) described by Bouton et al (1994); integration of data was performed with COCONUT software (Almanza and Mielle, INRA Dijon, France); profiles were divided into 30 areas.

\section{Frequency of analysis during ripening}

The $\mathrm{pH}, \mathrm{DM}, \mathrm{TN}, \mathrm{WSN}$ and PTASN were measured at $20 \mathrm{~h}, 3,12$ and 24 weeks; MNFC and Ca at $20 \mathrm{~h} ; \mathrm{S} / \mathrm{M}$ at 3 weeks; D- and L-lactate and VFA at 3, 12 and 24 weeks; urea-PAGE at 12 and 24 weeks and RP-HPLC profiles only at 24 weeks.

\section{Sensory analysis}

At the end of ripening, the mini-cheeses were submitted to a panel of ten persons from INRA for sensory analysis (AFNOR, 1988). They were trained to taste Swiss-type cheeses for two months before the analysis, but all of them were familiar with Comté cheese sensory evaluation. Six months elapsed between the tests on winter and autumn cheeses, but assessor training was maintained during this time.

Each seasonal group of cheeses was tasted over three consecutive days, and four samples were presented at each time, corresponding to the same day of cheese-making.

Cheese samples were cut into small cubes $\left(1 \mathrm{~cm}^{3}\right)$ and placed in Petri dishes. A portion of cheese was grated, mixed and put in small bottles for sniffing. Petri dishes and bottles were stored at $14{ }^{\circ} \mathrm{C}$ until utilisation. Analyses were performed in individual red light boxes. It was specified to assessors to first study odours of the four samples before tasting. The order of smelling and tasting was determined according to the tables of McFie et al (1989).

A total of 19 indicators, divided into four categories, was used to characterise each cheese: a) odour indicators (5): general intensity (INT-O), pungent (PUN-O), nutty (NUT-O), fruity (FRUT-O), buttery (BUTT-O). The fruity score here referred to a fruit-like smell and not to the overall flavour intensity, as is sometimes specified for Comté (Berdagué and Grappin, 1988); b) taste indicators (3): salted (SALT), acid (ACID) and bitter (BITT); c) gustative aroma indicators (8): general intensity (INT), pungent (PUNG), nutty (NUT), buttery (BUTT), rustic (RUST), rancid (RANC), propionic (PROP) and off-flavour (OFF). Rustic aroma was defined to quantify the level of ripening, an 'old' cheese being more rustic than a 'young' one; d) texture indicators (3): firmness (FIRM), elasticity (ELAS) and granulosity (GRAN). Each indicator was evaluated on a scale ranging from 0 (no perception) to 10 . Assessors were asked to use the entire scale.

\section{Statistical analysis}

Correlation, variance analysis and díscriminant factorial analysis (DFA) between variables were performed using the STATITCF software (5th version, 1991, Institut Technique des Céréales et des Fourrages, Paris, France). Results of microbial measurements presented in the first article (Demarigny et al, 1996) were added for DFA calculation. Data from sensory analysis were translated and scaled to increase discriminant efficiency (Berdagué and Grappin, 1991).

For DFA, the influence of each variable was tested on its ability to separate the four groups, with a $5 \%$ tolerance level. Only the most discriminant factors were kept. Moreover, if two variables were too closely correlated, ie, $r^{2}>0.9$, one of the two was rejected. 


\section{RESULTS}

\section{Gross composition of cheeses}

Table I shows the average physico-chemical characteristics of winter and autumn minicheeses. A one-way variance analysis showed no significant difference between the groups of cheeses for MNFC, S/M, Ca and 20-h dry matter (DM), irrespective of the cheese. Only 24-week DM varied slightly between A, B, C and $\mathrm{T}$ cheeses, although no systematic tendancy arose.

It is important to note that the DM content was significantly higher for winter cheeses than for autumn cheeses. As a consequence, MNFC and $\mathrm{S} / \mathrm{M}$, which included DM for calculation, also differed. These differences necessitated the separate analysis of winter and autumn cheeses.

\section{Biochemical composition of cheeses}

Discriminant factorial analysis of biochemical, physico-chemical and microbiological data was performed on winter and autumn results obtained at 12 weeks (fig 2) and 24 weeks (fig 3). At $20 \mathrm{~h}$ and 3 weeks, cheeses were too young to display even slight differences.

In figure 2 , axis 1 is mainly related to fermentation products; axis 2 does not seem to be linked to any specific variables. It can be seen that cheeses are grouped into four clusters according to origin (A, B and C) or absence ( $T$ ) of microflora. There is no significant influence of the day of cheese-making, although winter cheeses are better clustered than autumn cheeses. Considering the inertia of axis 1 - respectively $67 \%$ for winter and $96 \%$ for autumn data - we can argue that discrimination of 12-week old cheeses was essentially based on propionic acid fermentation parameters.

$\mathrm{T}$ cheeses were characterised by high concentrations of D- and L-lactate and low concentrations of $\mathrm{C}_{2}$ and $\mathrm{C}_{3}$ (table II). Indeed, the other variables (microbial counts and proteolytic data) were always measured at a lower level in reference than in 'raw milk' cheeses.
In both seasons, except for lactates in winter, A and B cheeses were characterised by a strong propionic fermentation with higher concentrations of $\mathrm{C}_{3}$ and $\mathrm{C}_{2}$ and lower concentrations of D- and L-lactate than in $\mathrm{C}$ cheeses.

It is also possible to differentiate between the cheeses on the basis of secondary proteolytic


Fig 2. Discriminant factorial analysis of biochemical, physico-chemical and microbiological data obtained at 12 weeks in winter and autumn cheeses: $\mathrm{C}_{2}$ : acetic acid, $\mathrm{C}_{3}$ : propionic acid, $\mathrm{iC}_{5}$ : isovaleric acid, $\mathrm{C}_{4}$ : butyric acid, LAD, LAL: D- and L-lactic acid, WSN/TN: water-soluble nitrogen on total nitrogen, PTASN/TN: phosphotungstic acid-soluble nitrogen on total nitrogen, FH Lb: facultatively heterofermentative lactobacilli, Th Lb: thermophilic lactobacilli, Th St: thermophilic streptococci.

Analyse factorielle discriminante des données biochimiques, physico-chimiques et microbiologiques obtenues à 12 semaines sur les fromages d'hiver et d'automne: $C_{2}$ : acide acétique, $C_{3}$; acide propionique, $i C_{5}$ : acide isovalérique, $C_{4}$ : acide butyrique, $L A D, L A L$ : acides D-et L-lactique, WSN/TN: rapport de l'azote soluble dans l'eau sur l'azote total, PTASN/TN: rapport de l'azote soluble dans l'acide phosphotungstique sur l'azote total, FH Lb: lactobacilles hétérofermentaires facultatifs, Th $L b$ : lactobacilles thermophiles, Th St: streptocoques thermophiles. 
Table I. Means of the physico-chemical characteristics of 'raw milk' (A, B, C) and control (T) cheeses made in winter and in autumn.

Moyennes des principales caractéristiques physico-chimiques des fromages «crus» $(A, B, C)$ et témoins $(T)$ d'hiver et d'automne.

\begin{tabular}{|c|c|c|c|c|c|c|c|}
\hline & \multirow[t]{2}{*}{ Cheese type } & \multirow[t]{2}{*}{$\mathrm{n}$} & \multirow{2}{*}{$\begin{array}{c}M N F C \\
20 \mathrm{~h}\end{array}$} & \multirow{2}{*}{$\begin{array}{c}S / M \\
3 \text { weeks }\end{array}$} & \multirow{2}{*}{$\begin{array}{l}\text { Calcium } \\
20 \mathrm{~h}\end{array}$} & \multicolumn{2}{|c|}{$D M$} \\
\hline & & & & & & $20 \mathrm{~h}$ & 24 weeks \\
\hline \multirow[t]{4}{*}{ Winter cheeses } & $\mathrm{T}$ & 3 & 51.6 & 1.57 & 2.25 & 65.0 & $67.8^{a}$ \\
\hline & A & 3 & 52.2 & 1.71 & 2.22 & 64.7 & $67.0 \mathrm{a}, \mathrm{b}$ \\
\hline & B & 3 & 52.0 & 1.55 & 2.24 & 65.1 & $66.5^{b}$ \\
\hline & C & 3 & 51.9 & 1.50 & 2.22 & 64.8 & $67.8^{a}$ \\
\hline Variance analysis & & & NS & NS & NS & NS & * \\
\hline \multirow[t]{4}{*}{ Autumn cheeses } & $\mathrm{T}$ & 3 & $53.5^{b}$ & 1.83 & 2.13 & 63.9 & $63.5^{b}$ \\
\hline & A & 3 & $54.2^{\text {a }}$ & 1.86 & 2.13 & 63.6 & $63.9 \mathrm{a}, \mathrm{b}$ \\
\hline & B & 3 & $53.7^{a}$ & 1.89 & 2.13 & 64.3 & $64.4^{\mathrm{a}}$ \\
\hline & $\mathrm{C}$ & 3 & 54.9 a & 1.84 & 2.14 & 63.9 & $64.1 \mathrm{a}, \mathrm{b}$ \\
\hline Variance analysis & & & $* *$ & NS & NS & NS & $*$ \\
\hline
\end{tabular}

MNFC: moisture in non-fat cheese (\%); Calcium: mg/100 g non-fat dry matter. DM: dry matter (\%), $n$ : number of cheeses, a, b Results of Newman-Keuls' test. Variance analysis: NS: not significant; ${ }^{*}$ significant at $P<0.05$; ** significant at $P<0.01$.

MNFC : humidité dans le fromage dégraissé (\%) ; calcium : $\mathrm{mg} / 100 \mathrm{~g}$ de matière sèche dégraissée ; DM : extrait sec (\%) ; $\mathrm{n}$ : nombre de fromages. ${ }^{a}{ }^{b}$ Résultats du test de Newman-Keuls. Analyse de variance : NS : non significant; * significatif à $\mathrm{p}<0,05 ; * *$ significatif à $\mathrm{p}<0,01$.

criteria, but differences are not as important as for fermentation products. Nevertheless, B and A cheeses were the most degraded, followed by $\mathrm{C}$ cheeses. These tendencies were noticed in winter and in autumn for the two ratios WSN/TN and PTASN/TN (table II); $\mathrm{iC}_{5}$, originating from isoleucine, leucine and valine breakdown (Bosset et al, 1993), was measured at a higher concentration in B than in A and C cheeses. The differentiation between these two cheeses on $\mathrm{iC}_{5}$ changed in winter and autumn, and no tendency appeared.

Cheeses could be also separated according to their $\mathrm{C}_{4}$ concentration irrespective of the season. As previously stated with $\mathrm{iC}_{5}$, the highest quantities of $\mathrm{C}_{4}$ were found in $\mathrm{B}$ and $\mathrm{A}$ cheeses, followed by $\mathrm{C}$ cheeses.
Finally, C winter cheeses were characterised by slightly higher levels of facultatively heterofermentative lactobacilli and lower levels of starter bacteria. These systematic differences, although non-significant, were also found in autumn.

Biochemical composition differed between $\mathrm{T}$ cheeses and A, B and C cheeses irrespective of the season. The highest $\mathrm{D}$ - and L-lactate concentrations and the lowest $\mathrm{C}_{2}$ and $\mathrm{C}_{3}$ concentrations were still found in $\mathrm{T}$ cheeses. Proteolysis was also less intense (table II).

The D- and L-lactate concentrations of 24-week 'raw milk' cheeses were identical in winter and in autumn. Therefore, discrimination was mainly based on secondary proteolysis. 
Table II. Means of some biochemical characteristics of 'raw milk' (A, B, C) and control (T) cheeses made in winter and in autumn after 12 weeks of ripening. Moyennes de quelques caractéristiques biochimiques des fromages «crus» $(A, B, C)$ et témoins $(T)$ d'hiver et d'automne, âgés de 12 semaines.

\begin{tabular}{|c|c|c|c|c|c|c|c|c|c|c|}
\hline & Cheese type & D-Lactate & L-Lactate & Acetate & Propionate & Butyrate & Isovalerate & Caproate & WSN/TN & PTASN/TN \\
\hline \multirow[t]{3}{*}{ Winter cheeses } & $\mathrm{T}$ & $417.3^{a}$ & $738.7^{\mathrm{a}}$ & $91.1^{b}$ & $70.4^{b}$ & $6.1^{\mathrm{b}}$ & $0.8^{b}$ & 2.5 & $17.5^{\mathrm{c}}$ & 5.0 \\
\hline & B & $58.7^{\mathrm{b}}$ & $156.3^{b}$ & $299.1^{\text {a }}$ & $512.0^{\mathrm{a}}$ & $7.7^{\mathrm{a}}$ & $4.0^{\mathrm{a}}$ & 4.1 & $19.3 \mathrm{a}$ & 7.0 \\
\hline & $\mathrm{C}$ & $117.7^{b}$ & $145.7^{b}$ & $265.3^{\text {a }}$ & $448.8^{a}$ & $6.4^{b}$ & $3.4^{\mathrm{a}}$ & 4.0 & $18.2^{b}$ & 6.0 \\
\hline \multirow[t]{4}{*}{ Autumn cheeses } & $\mathrm{T}$ & 256.6 & $573.5^{\text {a }}$ & $148.0^{\mathrm{b}}$ & 325.5 & 3.9 & 0.9 & 2.2 & $22.6^{b}$ & $5.7^{\mathrm{d}}$ \\
\hline & A & 78.1 & $143.1^{\mathrm{b}}$ & 394.2 a & 591.1 & 6.9 & 2.0 & 2.9 & 25.1 a & $9.0^{\mathrm{b}}$ \\
\hline & B & 69.4 & $121.5^{b}$ & $446.4^{\text {a }}$ & 713.1 & 7.7 & 2.5 & 4.3 & $25.0^{\mathrm{a}}$ & $10.2^{\mathrm{a}}$ \\
\hline & $\mathrm{C}$ & 184.5 & $207.9^{b}$ & $298.6^{a, b}$ & 530.7 & 5.7 & 1.8 & 3.8 & $25.4^{\mathrm{a}}$ & $8.2^{\mathrm{c}}$ \\
\hline
\end{tabular}

LAD, LAL: D- and L-lactate (mg/100 g). Acetate, propionate, butyrate, isovalerate and caproate (mg/l00 g). WSN/TN: water-soluble nitrogen on total nitrogen (\%). PTASN/TN: phosphotungstic acid-soluble nitrogen on total nitrogen (\%), a, b, c, d: Results of Newman-Keuls' test. Variance analysis: NS: not significant; * significant at $P<0.05$; ** significant at $P<0.01$; *** significant at $P<0.001$.

LAD, LAL : acides D-et L-lactique ( $\mathrm{mg} / 100 \mathrm{~g}$ ). Acetate, propionate, butyrate, isovalerate et caproate ( $\mathrm{mg} / 100 \mathrm{~g})$. WSN/TN : azote soluble dans l'eau rapporté à l'azote total (\%). PTASN/TN : azote soluble dans l'acide phosphotungstique rapporté à l'azote total (\%). a, b,c, d : Résultats du test de Newman-Keuls. Analyse de variance : NS : non significatif; * significatif à $\mathrm{P}<0,05$; $* *$ significatif à $\mathrm{P}<0,01 ; * * *$ significatif à $\mathrm{P}<0,001$. 
Table III. Means of some biochemical characteristics of 'raw milk' (A, B, C) and control (T) cheeses made in winter and in autumn after 24 weeks of ripening. Moyennes de quelques caractéristiques biochimiques des fromages «crus» $(A, B, C)$ et témoins $(T)$ d'hiver et d'automne, âgés de 24 semaines.

\begin{tabular}{|c|c|c|c|c|c|c|c|c|c|c|}
\hline & Cheese type & D-Lactate & L-Lactate & Acetate & Propionate & Butyrate & Isovalerate & Caproate & WSN/TN & PTASN/TN \\
\hline \multirow{3}{*}{ Winter cheeses } & $\mathrm{T}$ & $205.3^{\text {a }}$ & $366.7^{a}$ & $229.2^{b}$ & 451.8 & $8.4^{c}$ & $2.6^{b}$ & 6.0 & $21.4^{\mathrm{c}}$ & $5.7^{b}$ \\
\hline & B & $21.3^{b}$ & $21.3^{b}$ & $384.2^{\mathrm{a}}$ & 767.6 & $11.0^{\mathrm{a}}$ & $7.6^{\mathrm{a}}$ & 10.5 & $22.9^{a}$ & $9.7 \mathrm{a}$ \\
\hline & $\mathrm{C}$ & $18.7^{b}$ & $18.7^{b}$ & $343.2 \mathrm{a}$ & 714.1 & $9.1 \mathrm{~b}, \mathrm{c}$ & $6.7 \mathrm{a}$ & 7.0 & $22.0^{b}$ & $8.8^{\mathrm{a}}$ \\
\hline \multirow[t]{4}{*}{ Autumn cheeses } & $\mathrm{T}$ & 34.5 & 20.6 & $228.1 \pm 24.3$ & 625.4 & 5.4 & 2.9 & $3.3^{b}$ & $26.4^{b}$ & $7.9^{b}$ \\
\hline & A & 10.7 & 10.2 & 348.6 & 764.9 & 9.4 & 3.0 & $6.8^{a}$ & $27.7^{a}$ & $12.3^{\mathrm{a}}$ \\
\hline & B & 11.7 & 11.8 & 335.0 & 752.6 & 10.9 & 3.9 & $9.2^{\mathrm{a}}$ & $28.1^{\text {a }}$ & $13.7^{\mathrm{a}}$ \\
\hline & $\mathrm{C}$ & 29.6 & 29.3 & 364.4 & 773.1 & 8.8 & 4.4 & $8.3^{\text {a }}$ & $28.6^{a}$ & $11.8^{\mathrm{a}}$ \\
\hline
\end{tabular}

LAD, LAL: D- and L-lactate (mg/100 g). Acetate, propionate, butyrate, isovalerate and caproate $(\mathrm{mg} / 100 \mathrm{~g})$. WSN/TN: water-soluble nitrogen on total nitrogen (\%). PTASN/TN: phosphotungstic acid-soluble nitrogen on total nitrogen (\%). a, b, c; results of Newman-Keuls' test. Variance analysis: NS: not significant ; ${ }^{*}$ significant at $P<0.05$; $* *$ significant at $P<0.01$.

LAD, LAL : acides D- et L-lactique ( $\mathrm{mg} / 100 \mathrm{~g}$ ). Acétate, propionate, butyrate, isovalerate et caproate ( $\mathrm{mg} / 100 \mathrm{~g})$. WSN/TN : azote soluble dans l'eau rapporté à l'azote total (\%). PTASN/TN : azote soluble dans l'acide phosphotungstique rapporté à l'azote total (\%). a, b, c : Résultats du test de Newman-Keuls. Analyse de variance: NS: non significatif ; * significatif à $\mathrm{p}<0,05$; ** significatif à $\mathrm{p}<0,01$. 
Casein fractions were followed, but no difference was detected between cheeses (not shown). Hence, primary proteolysis did not seem to be influenced by the raw milk microflora.
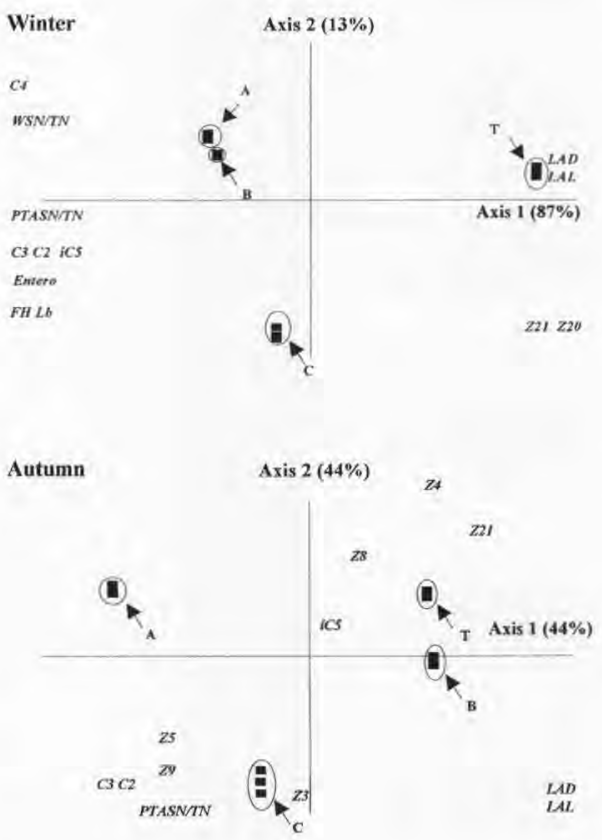

Fig 3. Discriminant factorial analysis of biochemical, physico-chemical and microbiological data obtained at 24 weeks of winter and autumn cheeses: $C_{2}$ : acetic acid, $\mathrm{C}_{3}$ :propionic acid, $\mathrm{iC}_{5}$ : isovaleric acid, $\mathrm{C}_{4}$ : butyric acid, LAD, LAL: D- and L-lactic acid, WSN/TN: water-soluble nitrogen on total nitrogen, PTASN/TN: phosphotungstic acid-soluble nitrogen on total nitrogen, Z3, 4, 5, 8, 9, 20, 21: HPLC areas, FH Lb: facultatively heterofermentative lactobacilli, entero: enterococci.

Analyse factorielle discriminante des données biochimiques, physico-chimiques et microbiologiques obtenues à 24 semaines sur les fromages d'hiver et d'automne: $C_{2}$ : acide acétique : $C_{3}$ : acide propionique ; $i C_{5}$ : acide isovalérique; $C_{4}$ : acide butyrique ; LAD, LAL : acides D-et L-lactique ; WSN/TN : rapport de l'azote soluble dans l'eau sur l'azote total ; PTASN/TN : rapport de l'azote soluble dans l'acide phosphotungstique sur l'azote total ; Z3, 4, 5, 8, 9 , 20, 21 : zones de profil CLHP ; FH Lb: lactobacilles hétêrofermentaires facultatifs ; entero : entérocoques.
Secondary proteolysis was more intense in autumn than in winter cheeses (WSN/TN). Moreover, the quantity of small peptides and amino acids (PTASN/TN) was more important in the former than in the latter cheeses (table III). This was confirmed by RP-HPLC analysis (fig 4). Autumn cheeses were rather characterised by high quantities of medium-size hydrophobic peptides, corresponding to 20 and 21 areas. On the contrary, peptidic fractions of winter cheeses contained a higher proportion of small hydrophilic peptides and amino acids (Z3, Z4, Z5, Z8 and Z9).

The PTASN/TN ratio was rather lower in C cheeses than in $\mathrm{A}$ and $\mathrm{B}$ cheeses irrespective of the season. This tendency was also observed in winter with the WSN/TN ratio. In autumn, however, $\mathrm{C}$ cheeses exhibited the highest WSN/TN ratio. $\mathrm{A}$ and $\mathrm{B}$ cheeses were also characterised by higher concentrations of large-size peptides than the latter. In autumn, B cheeses exhibited the same peptide composition as C cheeses (table IV).

The concentration of $\mathrm{iC}_{5}$ was rather lower in autumn than in winter cheeses. Generally, C cheeses were characterised by lower quantities of this compound than A and B cheeses. This remark was also checked with $\mathrm{C}_{4}$ concentrations, although no seasonal variations were found.

Some microbial differences were found between winter cheeses. The level of facultatively heterofermentative lactobacilli in $\mathrm{C}$ cheeses was slightly higher than in $\mathrm{A}$ and $\mathrm{B}$ cheeses. However, the number of enterococci was identical among the three 'raw milk' cheeses, and significantly lower in $\mathrm{T}$ cheeses. These observations were not available for autumn cheeses, since no differences were found.

\section{Sensory analysis of cheeses}

Seven variables out of 22 were used to discriminate winter cheeses: propionic aroma, global aroma intensity, granular, acid, pungent, firm- 


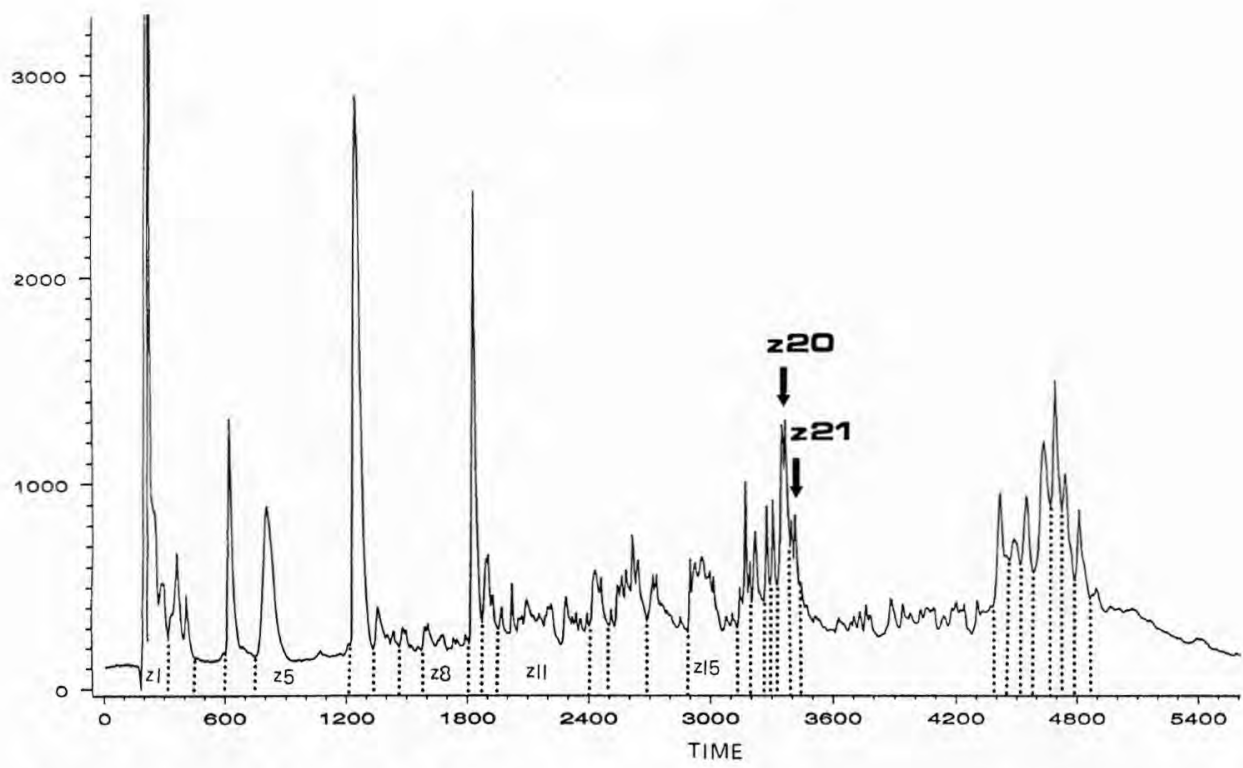

Fig 4. Example of HPLC profiles of the water-soluble fraction at 24 weeks of a 'raw milk' and microfiltered milk mini-cheese.

Exemple de profil CLHP de la fraction soluble dans l'eau à 24 semaines d'un minifromage fabriqué au «lait cru» et au lait microfiltré.

ness, butter aroma and global odour intensity (fig 5).

The four groups of cheeses appeared clearly separated. Hence, discrimination observed between cheeses on biochemical, physico-chemical and microbiological data was confirmed.

Compared to 'raw milk' cheeses scores, $\mathrm{T}$ cheeses were downgraded, except for the descriptive terms butter and nutty aroma. A and $\mathrm{B}$ cheeses were different from $\mathrm{C}$ cheeses. They had a more intense propionic aroma and were more pungent and acidic. However, they were characterised by a lower aroma intensity and were less firm. It was also possible to differentiate between A and B cheeses, since the latter had a more intense aroma than the former. Moreover, in A cheeses, assessors identified offflavours such as plastics, rind, oxidized and mushroom descriptive terms.
The following variables were used to separate autumn cheeses (fig 5): pungent, pungent odour, rancid, rustic, salted, propionic aroma, global aroma intensity. As previously stated for winter cheeses, sensory discrimination confirmed biochemical, physico-chemical and microbiological conclusions.

A and B cheeses were very close, and had a global aroma intensity which was more important than in $\mathrm{C}$ cheeses. They were also more rustic, more rancid and had a more intense propionic aroma. Sensory profiles of T cheeses were opposite to those of $\mathrm{A}$ and $\mathrm{B}$ cheeses. $\mathrm{C}$ cheeses were intermediate between these two groups.

\section{DISCUSSION}

During this experiment, the biochemical characteristics of 'raw' and microfiltered milk 
Table IV. Means of HPLC areas of 'raw milk' (A, B, C) and control (T) cheeses made in winter and in autumn after 24 weeks of ripening. Moyennes des aires de CLHP des fromages «crus» $(A, B, C)$ et témoins $(T)$ d'hiver et d'automne, âgés de 24 semaines.

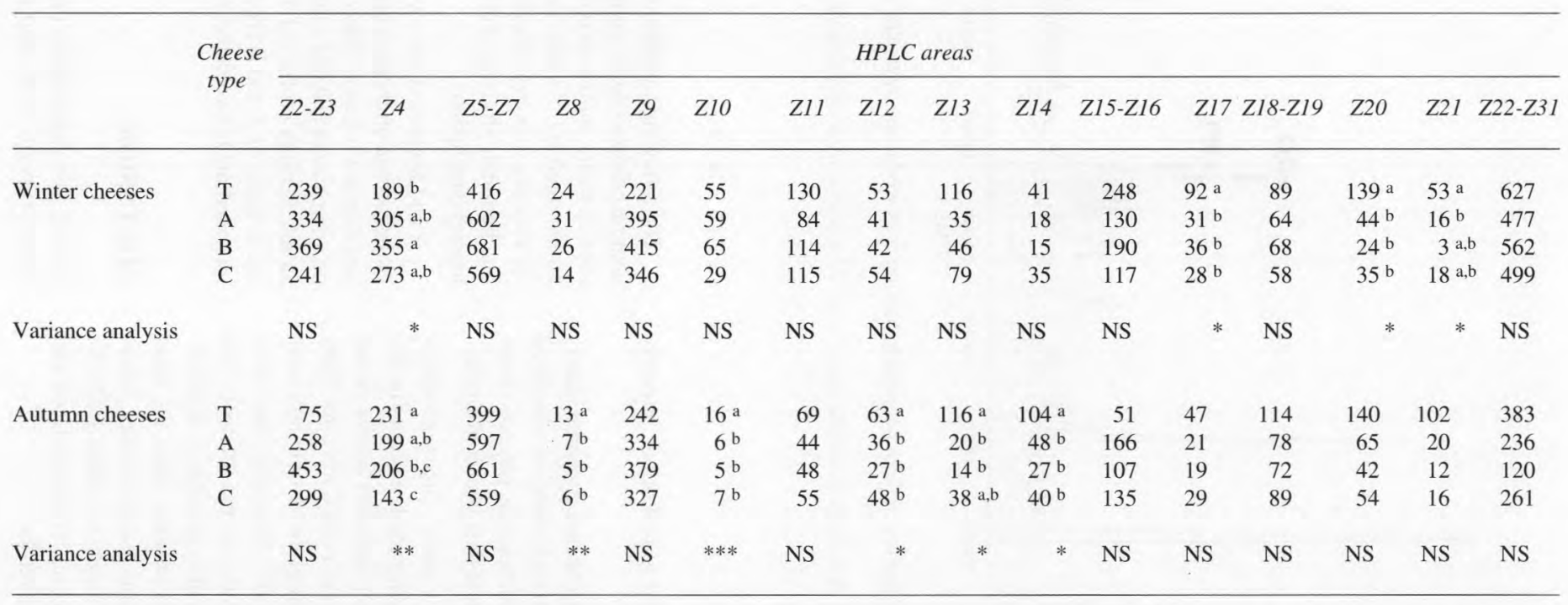

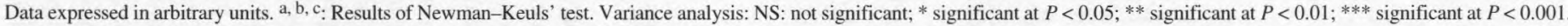

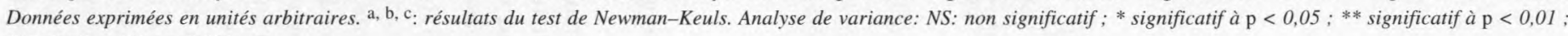
*** significatif à $\mathrm{p}<0,001$. 
cheeses made in winter and autumn were followed throughout the ripening period. In particular, proteolysis and propionic acid fermentation were studied, since these two metabolic processes are essential to obtain a Swiss-type cheese with typical characteristics.

The physico-chemical parameters of the minicheeses were nearly identical to the results
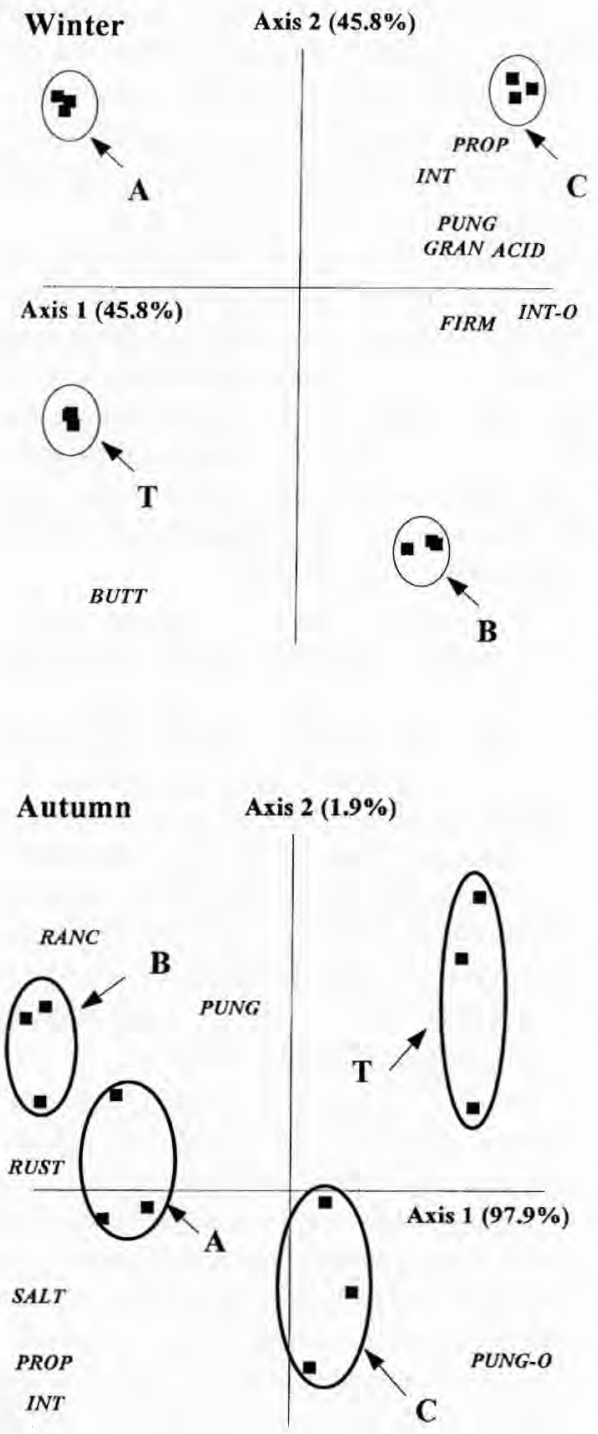

obtained by Bouton and Grappin (1995) and Beuvier et al (pers obs), except for the S/M ratio. Winter cheeses were found to have a significantly higher DM than autumn cheeses, mainly because the draining temperature during pressing was modified between the two trials. Because this high DM may have modified microbial development and biochemical evolution, multifactorial analyses were carried out separately for winter and autumn cheeses.

During ripening, $\mathrm{C}_{2}$ and $\mathrm{C}_{3}$ concentrations increased as a result of D- and L-lactate consumption. Quantities of these two VFA in 'raw milk' cheeses were respectively 1.7 - and 3.0fold higher compared with data obtained by Bouton and Grappin (1994) on Swiss-type minicheeses. However, the latter authors ripened their cheeses for four months only. The same differences were also noticed between our results and the values reported by Berdagué et al (1987) on Comté cheeses. The small size of minicheeses and the wax used to avoid smear development probably modified gas exchanges and the fermentation process. The evolution of proteolytic parameters (WSN/TN, PTASN/TN) also differed from the results obtained by Bouton and Grappin (1995). Nevertheless, these authors used a more proteolytic starter.

During the first 12 weeks, the biochemical characteristics of winter and autumn cheeses

Fig 5. Discriminant factorial analysis of sensory data obtained on winter and autumn cheeses at 24 weeks: INT-O: global odour intensity; PUN-O: pungent odour; ACID: acid; SALT: salty; BITT: bitter; INT: global aroma intensity; PUNG: pungent; NUT: nutty aroma; BUTT: butter aroma; RANC: rancid; RUST: rustic; PROP: propionic aroma; GRAN: granular; FIRM: firmness.

Analyse factorielle discriminante des données sensorielles obtenues sur les fromages d'hiver et d'automne à 24 semaines: INT-O : intensité globale de l'odeur; $P U N-O$ : odeur piquante; $A C I D$ : acide ; SALT : salé ; BITT : amer, INT : arôme, intensité globale; PUNG : arôme piquant ; NUT : arôme de noisette ; BUTT : arôme de beurre, RANC : rance ; RUST : rustique ; PROP : arôme propionique : GRAN : granuleux; FIRM : fermeté. 
evolved slowly, since significant differences appeared only at the end of warm storage. At that time, cheeses were essentially differentiated on the basis of propionic acid fermentation products, ie, DL-lactate, $\mathrm{C}_{2}, \mathrm{C}_{3}$, and to a lesser extent on proteolysis and microbial data. Although some differences were found between autumn and winter cheeses, the same tendencies were observed.

Reference cheeses were characterised by higher concentrations of $\mathrm{D}$ - and L-lactate and lower concentrations of $\mathrm{C}_{2}, \mathrm{C}_{3}$ and proteolytic products than 'raw milk' cheeses. This is not surprising, since it was noticed that the growth of propionibacteria as well as other adventitious populations was delayed as a consequence of microfiltration (Demarigny et al, 1996).

The quantity of VFA produced in C cheeses was slightly lower compared with concentrations measured in A and B cheeses, and in proportion the quantity of lactate was higher. No significant difference was detected between the levels of propionibacteria in the three 'raw milk' cheeses. Therefore, we can assume that the strain composition of this population was different. Hence, the metabolism of propionibacteria from milks A and B was more efficient compared to the bacteria in milk $\mathrm{C}$; or species present in $\mathrm{C}$ cheeses interfered with starter bacteria, as specified by Perez-Chaia et al (1987), and propionic acid fermentation was disturbed.

Some differences were also noticed in proteolytic data. Proteins of A and B winter cheeses were more degraded than proteins of $\mathrm{C}$ winter cheeses. This difference was observed in autumn, but the order of classification differed. Among microbial populations, facultatively heterofermentative lactobacilli are potentially highly proteolytic (Khalid and Marth, 1990). After 12 weeks of ripening, they have already reached their maximum level (Demarigny et al, 1996). However, they were 1.5 to 2 times more numerous in C cheeses than in A and B cheeses, irrespective of the season. As a consequence, $\mathrm{C}$ cheeses probably included weakly proteolytic strains. After biochemical characterisation of some lactobacilli strains, we only found two main species in all the cheeses: Lactobacillus paracasei subsp paracasei 1 and 3 . However, according to Peterson and Marshall (1990), the proteolytic system of lactobacilli varies widely even among subspecies.

Facultatively heterofermentative lactobacilli could also be responsible for differences in $\mathrm{iC}_{5}$ concentrations (Langsrud and Reinbold, 1973) as well as propionibacteria (Paulsen et al, 1980). In the last case, it would again ascertain that strain composition of this population was different, since microbial levels were identical.

Cheeses could be finally separated on their $\mathrm{C}_{4}$ concentration. This product may result from lipolysis, butyric fermentation or amino acid breakdown (Bosset et al, 1993). The level of butyric acid bacteria always being lower than one cell per gramme, no butyric acid fermentation occurred. Since the physico-chemical composition of milk used for cheese-making was the same for the four mini-cheeses, differences in $\mathrm{C}_{4}$ concentrations were probably due to the lipolytic activity of microorganisms (Khalid and Marth, 1990; Dupuis, 1994).

It was already possible to separate cheeses at 12 weeks on the basis of their biochemical characteristics according to the presence or the absence of 'raw milk' microflora. In particular, the strain composition of the two main microbial populations at that time, ie, facultatively heterofermentative lactobacilli and propionibacteria, was probably responsible for this early discrimination. Nevertheless, other microorganisms may have also interfered directly by their metabolic activity, eg, enterococci, or indirectly by interactions, eg, starter bacteria.

Except between reference and 'raw milk' cheeses, propionic acid fermentation parameters did not allow any discrimination at 24 weeks. T cheeses were always characterised by low VFA concentrations, high DL-lactate concentrations and proteolysis was less intense. It is noteworthy that the differences observed at 12 weeks remained at 24 weeks, even if adventitious populations of reference cheeses reached the same level as in 'raw milk' cheeses. 
Differentiation of 'raw milk' cheeses was based on secondary proteolysis. Proportions of casein fractions resulting from primary proteolysis were similar, irrespective of the cheese. This is in agreement with conclusions made by McSweeney et al (1993a), who noticed that indigenous microflora had no influence on primary proteolysis.

Concerning secondary proteolysis, autumn cheeses were more degraded than winter cheeses. Moreover, proteolytic products were larger in size and rather hydrophobic. Collin et al (1988) already noted a seasonal effect on secondary proteolysis. Nevertheless, the classification of cheeses was identical in winter and in autumn: $\mathrm{C}$ cheeses were less degraded than $\mathrm{A}$ and B cheeses. As previously stated at 12 weeks, we can assume the existence of a difference in proteolytic activity between adventitious microflora, such as facultatively heterofermentative lactobacilli and enterococci. Moreover, starter bacteria were enumerated at a level $10^{2}$ to $10^{3}$ times lower compared to their level at $20 \mathrm{~h}$. They may have released many enzymes in the cheese after autolysis, and also contributed to ripening (Lortal, 1995). As autolysis depends on many variables such as nutritional competition, we can argue that the strain composition of other flora may have enhanced or inhibited cell death. Hence, Bouton and Grappin (1995) specified that the aroma typicity of raw milk mini-cheeses compared with microfiltered mini-cheeses was due to the combined action of starter lactic acid bacteria and adventitious milk microflora present in the milk.

Biochemical differences between 'raw milk' cheeses were comfirmed by sensory analyses. As expected, reference cheeses were separated from 'raw milk' cheeses in winter and in autumn. Generally, they exhibited much lower scores except for the buttery and nutty aroma. Beuvier et al (pers obs) obtained similar results in discriminating 'raw' and microfiltered milk cheeses. However, for Cheddar cheeses, McSweeney et al (1993a) made different conclusions. Raw milk
Cheddar cheeses were downgraded due to too strong a flavour compared with microfiltered and pasteurised milk Cheddar cheeses. They also indicated that, although atypical, raw milk Cheddar might have been more attractive to connoisseurs of traditional cheeses.

We also noticed that sensory profiles of A and $\mathrm{B}$ cheeses were close, and different to those from $C$ cheeses. Variables used to characterise cheeses changed from winter to autumn, but the classification remained the same. Frequently, differences between 'raw milk' cheeses were not important, even if they were significant. However, it is probable that a longer ripening time would have increased the discrimination.

\section{CONCLUSIONS}

From a biochemical and a sensory point of view, early discrimination of 'raw milk' cheeses after 12 weeks was confirmed at the end of ripening. It is assumed that adventitious microflora are responsible for these biochemical and sensory differences between cheeses, and especially as regards facultatively heterofermentative lactobacilli and propionibacteria. However, it seems that these populations are as important quantitatively as qualitatively. Moreover, the relations that link bacteria in terms of competition or commensalism are still unknown; cheese is a dynamic ecosystem which evolves constantly. Comprehension of this evolution implies determination of the role and behaviour of each population individually, and thereafter in association.

From this preliminary study of the Swisstype cheese ecosystem, three main conclusions can be made: 1) milk microflora have a significant influence on the biochemical and sensory characteristics of 'raw milk' cheeses; 2) there is also a significant influence of microflora origin on the characteristics of cheeses; 3 ) there is a probable 'specificity' of the flora according to the origin of the milk. 


\section{ACKNOWLEDGMENTS}

The authors thank MH Duployer and F Saad for technical assistance. This project was supported by the regional council of Franche-Comté (contract no BTH00252) and by INRA (AIP 4926).

\section{REFERENCES}

Adda J (1987) Les propriétés organoleptiques des fromages. 2. La formation de la flaveur. In: Le Fromage (Eck A, ed) Lavoisier, Paris, 330-340

Adda J, Gripon JC, Vassal L (1982) The chemistry of flavour and texture generation in cheese. Food Chem 9, 115-129

AFNOR (1988) Contrôle de la qualité des produits alimentaires - analyse sensorielle - méthodologie. NF V09-016

Berdagué JL, Grappin R (1988) Affinage et qualité du Gruyère de Comté. VI. Caractéristiques sensorielles des fromages. Lait 68, 189-204

Berdágué JL, Grappin R (1991) Caractérisation sensorielle des aliments par analyse factorielle discriminante: l'apport du centrage et de la réduction des données. Lebensm Wiss Technol 24, 298-302

Berdagué JL, Jeunet R, Grappin R (1987) Affinage et qualité du Gruyère de Comté. III. Fermentation lactique et teneur en acides gras volatils des fromages de Comté, Lait 67, 249-263

Bhowmik T, Marth EH (1990) Role of Micrococcus and Pediococcus species in cheese ripening: a review. J Dairy Sci 73, 859-866

Bosset JO, Collomb M, Sieber R (1993) The aroma compound of Swiss-type cheese. IV. The acidic volatile components and their changes in content during ripening. Lebensm Wiss Technol 26, $581-592$

Bouton Y, Grappin R (1995) Comparaison de la qualité de fromages à pâte pressée cuite fabriqués à partir de lait cru ou microfiltré. Lait 75, 31-44

Bouton Y, Guyot P, Dasen A, Grappin R (1994) Activité protéolytique de souches de lactobacilles thermophiles isolées de levains et de Comté. II. Applications en sites industriels. Lait 74, 33-46

Collin JC, Bergagué JL, Dognin-Bergeret M, Grappin R (1987) Affinage et qualité du Gruyère de Comté. IV. Étude de la protéolyse. Lait 67, 299-318

Demarigny Y, Beuvier E, Dasen A, Duboz G (1996) Influence of raw milk microflora on characteristics of Swiss-type cheeses. I. Evolution of microflora during ripening and characterization of facultatively heterofermentative lactobacilli. Lait 76 , 371-387

Dupuis C (1994) Activités protéolytiques et lipolytiques des bactéries propioniques laitières. Thesis, ENSA, Rennes

Dupuis C, Corre C, Boyaval P (1995) Protease activity of dairy Propionibacterium. Appl Microbiol Biotechnol 42, 750-755

FIL-IDF (1982) Fromages et fromages fondus. Détermination de l'extrait-sec total; méthode de référence. FIL-IDF, Standard $4 \mathrm{~A}$

Fox PF, Stepaniak L (1993) Enzymes in cheese technology. Int Dairy J 3, 509-530

Gautier M, Lortal S, Boyaval P, Girard F, Lemée R, de Carvalho AF, Dupuis C (1993) Les bactéries propioniques. Lait 73, 257-263

Grappin R, Rank TC, Olson NF (1985) Primary proteolysis of cheese proteins during ripening: a review. J Dairy Sci 68, 531-540

Heiss (1961) Essais de dosage de la matière grasse dans le fromage par des méthodes rapides. Disch Molk Ztg 82, 67-70

Khalid NM, Marth EH (1990) Lactobacilli - their enzymes and role in ripening and spoilage of cheese: a review. J Dairy $S_{c i} 73,2669-2684$

Langsrud T, Reinbold GW (1973) Flavor development and microbiology of Swiss-type cheeses. A review. III. Ripening and flavor production. J Milk Food Technol 36, 593-609

Lemieux L, Simard RE (1991) Bitter flavour in dairy products. I. A review of the factors likely to influence its development, mainly in cheese manufacture. Lait 71, 599-636

Lortal S (1995) L'autolyse des bactéries, phénomène clé de l'affinage? Process 1111, 61-62

Matheson AR (1981) The immunochemical determination of chymosin activity in cheese. NZJ Dairy Sci Technol 15, 33-41

McFie HJ, Bratchell N, Greenhoff K, Vallis LV (1989) Designs to balance the effect of order of presentation and first-order carry-over effects in hall tests. J Sens Stud 4, 129-148

McSweeney PLH, Fox PF, Lucey JA, Jordan KN, Cogan TM (1993a) Contribution of the indigenous microflora to the maturation of Cheddar cheese. Int Dairy J 3, 613-634 
McSweeney PLH, Olson NF, Fox PF, Healy A, Højrup P (1993b) Proteolytic activity of chymosin on bovine $\alpha_{\mathrm{S} 1}$-casein. J Dairy Res $60,401-412$

Mocquot G (1979) Reviews of the progress of dairy science: Swiss-type cheeses. J Dairy Res 46, $133-160$

Monnet V, Condon S, Cogan TM, Gripon JC (1995) Metabolism of starter cultures. In: Dairy Starter Cultures (Cogan T, Accolas JP, eds) VCH Publ, New York

Paulsen PV, Kowalewska J, Hammond EG, Glatz BA (1980) Role of microflora in production of free fatty acids and flavour in Swiss cheese. J Dairy Sci 63, 912-918

Pearce KN (1977) The complexometric determination of calcium in dairy products. NZ J Dairy Sci Technol 12, 113-121
Perez-Chaia A, Pesce de Ruiz Holgado A, Oliver G (1987) Interaction between Lactobacillus helveticus and Propionibacterium freundenreichii subsp shermanii. Microbiol Aliments Nutr 5, 325-331

Peterson SD, Marshall RT (1990) Nonstarter lactobacilli in Cheddar cheese: a review. J Dairy Sci 73, 1395-1410

Rank TC, Grappin R, Olson NF (1985) Secondary proteolysis of cheese during ripening: a review. J Dairy Sci 68, 801-805

Steffen C, Flueckiger E, Bosset JO, Rüegg M (1987) Swiss-type varieties. In: Cheese: Chemistry, Physics and Microbiology. Vol 2. Major Cheese Groups (Fox PF, ed) Elsevier, London

Thomas TD (1987) Acetate production from lactate and citrate by non starter lactic acid bacteria in Cheddar cheese. NZ J Dairy Sci Technol 22, 25-28 